\title{
A new Micarea species from western Europe, belonging in the Micarea denigrata group
}

\author{
Pieter P.G. van Den Boom*, A. Maarten Brand, Brian J. Coppins \\ \& Emmanuël SÉRUSIAUX
}

\begin{abstract}
Boom P.P.G., Brand A.M., Coppins B.J. \& Sérusiaux E. 2018: A new Micarea species from western Europe, belonging in the Micarea denigrata group. - Herzogia 31: 385-389.

A new species of Micarea, M. sambuci is described from western Europe. Though it was common in the Netherlands and also present in Belgium, Luxemburg, Germany, and Scotland, it could now be extinct. It differs from M. nitschkeana by the production of mesoconidia $(2.7-4.1 \times 1.1-1.5 \mu \mathrm{m})$ and complete absence of micro- and macroconidia.
\end{abstract}

Zusammenfassung: van den Boom P.P.G., Brand A.M., Coppins B.J. \& SÉRusiaux E. 2018: Eine neue MicareaArt aus Westeuropa, die in die Micarea denigrata Gruppe gehört. - Herzogia 31: 385-389.

Eine neue Micarea-Art, M. sambuci, wird aus Westeuropa neu beschrieben. Obwohl die neue Sippe in den Niederlanden häufig zu finden war und auch in Belgien, Luxemburg, Deutschland und Schottland vorkam, könnte sie jetzt ausgestorben sein. Sie unterscheidet sich von Micarea nitschkeana durch die Bildung von Mesokonidien (2.7-4.1 × 1.1-1.5 $\mu \mathrm{m})$ und das völlige Fehlen von Mikro- und Makrokonidien.

Key words: Lichenized ascomycete, Lecanorales, taxonomy

\section{Introduction}

The genus Micarea is rather well represented in the Netherlands with 28 species (BLWG 2018), of which Micarea confusa Coppins \& van den Boom, M. herbarum Brand, Coppins, Sérus. \& van den Boom, M. subcinerea M.Brand \& van den Boom, $M$. viridileprosa Coppins \& van den Boom have been newly described during the last thirty years.

A revision of the herbarium material of Micarea specimens of the authors led to the discovery of a further undescribed species. Many specimens formerly named Micarea cf. nitschkeana belong to an undescribed species that is easily mistaken for M. nitschkeana (J.Lahm ex Rabenh.) Harm., a member of the Micarea denigrata (Fr.) Hedl. group (CopPINs 1983). It was common in the Netherlands (20 specimens have been found) but was also collected in Belgium (1 specimen), Germany (1 specimen), Luxemburg (2 specimens) and Scotland (3 specimens). The collections were made at a time when levels of atmospheric sulphur dioxide were very high. Because there are no recent collections, there is some likelihood that this new species is now extinct in the study area. The species is here formerly described as Micarea sambuci van den Boom, M.Brand, Coppins \& Sérus.

* Corresponding author 


\section{Material and Methods}

The studied specimens from The Benelux and Germany are kept in the private collections of the authors and LG. Collections of Micarea nitschkeana from E have also been studied. Hand-made sections were investigated microscopically in water and 5\% $\mathrm{KOH}$. Microscopic measurements all refer to material examined in water. Chemical reactions were tested using $10-15 \% \mathrm{KOH}(\mathrm{K})$ and Lugol's reagent without (I) or with (K/I) pre-treatment with K. Microcrystallization, used to identify gyrophoric acid follows ORANGE et al. (2010). Chemical compounds were studied by thin-layer chromatography (TLC) using standard methods (ORANGE et al. 2010).

\section{Taxonomy}

Micarea sambuci van den Boom, M.Brand, Coppins \& Sérus., species nova

(figure 1)

MycoBank number: MB 811051

Diagnosis: Thallus small, often diffuse and up to several $\mathrm{cm}$ wide, up to $0.3 \mathrm{~mm}$ thick, thallus granules $0.02-0.2 \mathrm{~mm}$ wide, greyish to greenish; apothecia $0.15-0.25 \mathrm{~mm}$ wide, marginate when young, becoming immarginate, pale to dark grey, pale pinkish to pale brownish; paraphyses markedly sinuous in upper part; ascospores slightly clavate, straight to slightly curved, (9.4-12.1 × 2.9-3.2 $\mu \mathrm{m})$, 3-septate; mesopycnidia abundantly present, hyaline to brownish at the top, immersed, 30-150(-250) $\mu \mathrm{m}$ diameter, $\mathrm{K}+$ violet, mesoconidia $2.7-4.1 \times 1.1-1.5 \mu \mathrm{m}$, gyrophoric acid present mainly in apothecia.

Type: The Netherlands, Noord-Brabant, E of Best, Nieuwe Heide, W of Joe Man theatre, open grassy place in Pinus forest, with Quercus robur, 51 $30.7^{\prime} \mathrm{N}, 5^{\circ}$ 26.0' E, on trunk of Quercus, 9 December 2000, P. \& B. van den Boom 25550 [holotype in L; isotype in herbarium v.d. Boom].

Etymology: The epithet chosen for this species refers to the substrate (Sambucus) on which it usually has been found.

Description: Thallus small, sometimes diffuse over larger areas, up to several cm, consisting of smaller $(0.02-0.2 \mathrm{~mm}$ wide) greyish to greenish granules, often growing with free living algae or fungi, then aggregated to an indistinct, up to $0.3 \mathrm{~mm}$ thick, scurfy farinose-granular crust. Thallus without a cortex, upper part with or without crystals, without pigments; algae 'micareoid', 5-7(-10) $\mu \mathrm{m}$. Apothecia to $c$. $0.15-0.25 \mathrm{~mm}$ wide, at first immersed in thalline warts, seemingly lecanorine, with a thin, clearly thalline margin, becoming sessile and margin finally evanescent; disc convex, pale to dark grey, pale pinkish to pale brownish, never black. Excipulum without algae, lateral to the top up to $20 \mu \mathrm{m}$ wide, with interwoven thin hyphae; an alga-containing layer below the apothecium is clearly present (e.g. $60 \mu \mathrm{m}$ ). Hymenium 25-45 $\mu \mathrm{m}$. Paraphyses thin, c. 1.1-1.4 $\mu \mathrm{m}$ wide (in $\mathrm{KOH}$ ), towards the top densely branched and distinctly sinuous. Epithecium greenish grey (K+ violet), sometimes too weak to detect. Hypothecium hyaline. Asci with a strongly amyloid apical dome, sometimes an apical cushion is visible, clavate, $25-36 \times 9-11 \mu \mathrm{m}$, 8-spored. Ascospores, ellipsoid to slightly clavate, straight to slightly curved, 9.4-12.1 × 2.9-3.2 $\mu \mathrm{m}$, (1-)3-septate. Mesopycnidia always present, usually abundant, immersed, 30-150(-250) $\mu \mathrm{m}$ wide, hyaline, or brownish pigmented at the top; if old, the ostiole often gaping; wall partly with crystals; mesoconidia 2.7-4.1 × 1.1-1.5 $\mu \mathrm{m}$. Macro- and micropycnidia not observed.

Chemistry: Gyrophoric acid, always present as polarized crystals in apothecia, in hymenium, epithecium, excipulum, and often in the pycnidial wall, but in thallus mostly lacking. Sedifolia grey (Pigment D in Coppins 1983; K+ violet) often present in epithecium and pycnidia.

Ecology and distribution: Micarea sambuci has been found on neutral bark, from Sambucus, Populus (P. tremula, P. alba), Salix, Ulmus, Quercus, and Fagus, often in dune areas (under influence of calcareous shifting sands), or on young trees (Salix) on clay soil (Biesbos, Flevopolder), old Sambucus bushes, especially on older, often dead branches, and young Ulmus. Outside The Netherlands it was collected on the Wadden Sea island Borkum in Germany, in Belgium in the dune area near De Panne, and in Luxemburg two times from Populus sp. In Great Britain it is known from Sambucus and dead 
stems of Ulex. The bark on which the new species has been found was influenced by sulphur dioxide, an airborne compound that was very common when coal was in more common use in western Europe at the time when most specimens were collected. The type collection represents a well-developed population on Quercus, but otherwise the new species was mostly well-developed on Sambucus.

Accompanying species from the studied specimens are Lecanora expallens (12x), Physcia tenella (9x), Lecanora conizaeoides, Lepraria incana (each 5x), Amandinea punctata, Parmelia sulcata (each 4x), Scoliciosporum gallurae, (3x), Hypogymnia physodes, Melanelixia subaurifera (each 2x), Candelariella reflexa, Cliostomum griffithii, Coenogonium pineti, Lecanora saligna, Micarea micrococca, M. nitschkeana, Phaeophyscia orbicularis, Xanthoria polycarpa, Bacidia sp., Lecanora sp. (each 1x).

Most collections of Micarea sambuci originate from 1981-1990 (13x), furthermore from 1970-1978 (4x), 1991-2000 (7x), 2000 (2x) and 2003 (1x). The number of records (collections) have undergone a strong decline in the last two decades, and it has not been collected since 2003.

Notes: Micarea sambuci belongs to the $M$. denigrata group and is most closely related to $M$. nitschkeana. The ascospores of the M. sambuci are rather similar to those of M. nitschkeana, but somewhat shorter. However the latter has two kinds of conidia: macroconidia 12-26 $\times 1 \mu \mathrm{m}$ and 1-3-septate, microconidia 5.5-7.5 $\times 0.7-0.8 \mu \mathrm{m}$. We have never observed mesoconidia in $M$. nitschkeana in our many collections. $M$. sambuci has only mesoconidia and we have not observed other conidia types.

Coppins (1983) mentioned mesopycnidia from Micarea nitschkeana and only once recorded a specimen with three kinds of conidia. We have carefully re-studied that specimen and it contains material of both species, M. nitschkeana and M. sambuci. It is the only known collection in which these two species grow close together. In this specimen the dark (nearly blackish) apothecia are from M. nitschkeana and the two kinds of conidia are present. $M$. sambuci has brown apothecia and the thallus is not clearly granular, but instead it is indistinctly sorediate and only mesoconidia are present, for further differences see table 1. The three kinds of conidia of Micarea nitschkeana, in CzARnota $(2007,131)$ are from different specimens, specimens with mesoconidia could refer to another species probably our new species. Pawel Czarnota kindly re-examined several Micarea nitschkeana specimens, mentioned in his study and his conclusion is that 'since I have not found mesopycnidia except when M. nitschkeana was mixed with M. prasina s.lat., then the mesopycnidia most probably belong to M. prasina' (pers. comm. P. Czarnota). In the field, Micarea sambuci can be overlooked for M. denigrata, especially if the former has brownish apothecia. Shade forms of Micarea globulosella (Nyl.) Coppins resemble the new species because of the pale grey apothecia, but the ascospores of this species are clearly different, fusiform-acicular and 13-26 × 2-2.5 $\mu \mathrm{m}$, and it has microconidia of 3.8-5.0 $\times 0.8-1 \mu \mathrm{m}$. BRAND et al. (2014), in a study of Micarea on Réunion Island (southern hemisphere), described a new species that may belong to the M. denigrata group, Micarea cilaoensis Brand, van den Boom \& Sérus.; it is a rather different species with $0-1$-septate ascospores and large macroconidia of 38-48 $\times 0.9-1.1 \mu \mathrm{m}$.

Specimens examined: Belgium, West Vlaanderen, De Panne, Duindoornpad, c. $250 \mathrm{~m}$ from beach, 51⒌6' $\mathrm{N}$, 2³3.9'E, Sambucus brushwood, on twigs and dead branches of Sambucus, 1988, M. Brand 17912 (hb. Brand). Germany, Niedersachsen, Wadden Sea Island Borkum, Tüskendör, Hinterwall, on Sambucus at base of sand dike, 1978, M. Brand 30479b (hb. Brand). - Luxemburg, Oesling, $2.8 \mathrm{~km}$ SSE of Troisvierges, along road Sassel to Maulusmillen (C.R.373), N of Héiseboesch, on Populus along river. IFBL J8.33, 1992, P. \& B. van den Boom 12559 (hb. v.d. Boom). Gutland, SW of Larochette, Meysembourg (W), roadside trees (Aesculus) and Populus in a meadow. IFBL L8.26, 2003, P. \& B. van den Boom 30778 (hb. v.d. Boom). - The Netherlands, Friesland, Ameland, Hollum, Lange Duinen, dune area, Sambucus brushwood, grid ref. 1-47-33, on Sambucus, 1995, P. van den Boom 17458 (hb. v.d. Boom). Flevoland, Oostelijk Flevoland, Roggebotzand, 0.9 km E of Roggebotplas, 52 $2^{\circ} 3.7^{\prime}$ N, 549.4'E, in Salix alba plantation, on Populus, 1990, M. Brand 23360 (hb. Brand). Noord-Holland, Heemskerk, Doornenvlak, dune area, $52^{\circ} 31.5^{\prime} \mathrm{N}, 4^{\circ} 37.2^{\prime} \mathrm{E}$, Populus at the edge of a forest in dune area, 1991 , M. Brand 25973 (hb. Brand); Haarlem, Noordzeekanaal, S-shore, near Spaarnwoude, 52²7.1'N, 4²40.7'E, young Ulmus along road, 2001, M. Brand 43793 (hb. Brand); Vogelenzang, AWD, binnenduin, 52¹9'N, 4³3'E, young Populus tremula in open dune area, 1989, M. Brand 19833 (hb. Brand); Overveen, Kraantje Lek, steep facing soil of dune, 52 23.0'N, 4³5.5'E, on Populus, 1989, M. Brand 21124 (hb. Brand). Zuid-Holland, Katwijk, Pan van Persijn, 52 $10.7^{\prime} \mathrm{N}, 4^{\circ} 23.7^{\prime} \mathrm{E}$, at the edge of dune area, Populus alba 1989, M. Brand 19851 (hb. Brand); ibid., dense Sambucus brushwood, on old Sambucus, 1989, M. Brand 19848 (hb. Brand); Wassenaar, Berkheide, dune area, $52^{\circ} 10.4^{\prime} \mathrm{N}, 4^{\circ} 21.8^{\prime} \mathrm{E}$, Sambucus brushwood nearby beach, 1989, M. Brand 22494 (hb. Brand); Meyendel, damp 
forest, 52 $2^{\circ} .5^{\prime} \mathrm{N}, 4^{\circ} 19.2^{\prime} \mathrm{E}$, on Populus tremula, 1982, M. Brand 30848 (hb. Brand); Oostvoorne, Van Itersonbos, near NW edge, open forest, in dune area, 51 $54.6^{\prime} \mathrm{N}, 4^{\circ} 3.8^{\prime} \mathrm{E}$, on Populus robusta, 1986, M. Brand 14056 (hb. Brand); Rhoonse Grienden, Oude Maas, near dike, 51 ${ }^{\circ} 50.7^{\prime} \mathrm{N}, 4^{\circ} 25.5^{\prime} \mathrm{E}$, on pollard willow, 1989, M. Brand 19938 (hb. Brand); $7 \mathrm{~km} \mathrm{~S}$ of Dordrecht, Prinsenheuvel, old Ulmus trees along small road, $51^{\circ} 45.3^{\prime} \mathrm{N}, 4^{\circ} 39.9^{\prime} \mathrm{E}$, on Ulmus, 1989, M. Brand 20593 (hb. Brand). Zeeland, Schouwen, Verklikkerduin, dune area, 5143.5'N, 343.1'E, on dead Sambucus, 1982, M. Brand 30894 (hb. Brand); Renesse, dune area direct after beach, near pole 6, Sambucus brushwood, 51 $44.1^{\prime} \mathrm{N}, 3^{\circ} 44.7^{\prime} \mathrm{E}$, on twigs of Sambucus, 1984, M. Brand 33791 (hb. Brand); Noord Beveland,

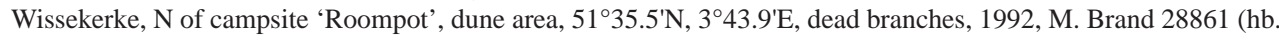

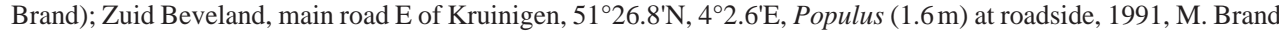
26465 (hb. Brand). Noord-Brabant, Biesbos, c. $0.2 \mathrm{~km}$ S of bridge of St Jan, edge of meadow, 51 ${ }^{\circ} 43.4^{\prime} \mathrm{N}, 4^{\circ} 50.3^{\prime} \mathrm{E}$, on Salix, 1995, M. Brand 33092 (hb. Brand); Bergeyk, Pinus Quercus forest, grid 57-23-45, 2000, P. \& B. van den Boom 24590 (hb. v.d. Boom). - United Kingdom, England, SE Yorkshire VC 61, Spurn Point, on Sambucus, 1970, D. Shimwell s.n. (E). Scotland, East Lothian, VC 82, Tyninghame, on Sambucus, 1975, B. Coppins 1241 (E); Westerness, VC 97, Loch Linnhe, Inverscaddle Bay, on dead stem of Ulex, 1978, B. Coppins 3369a (E).

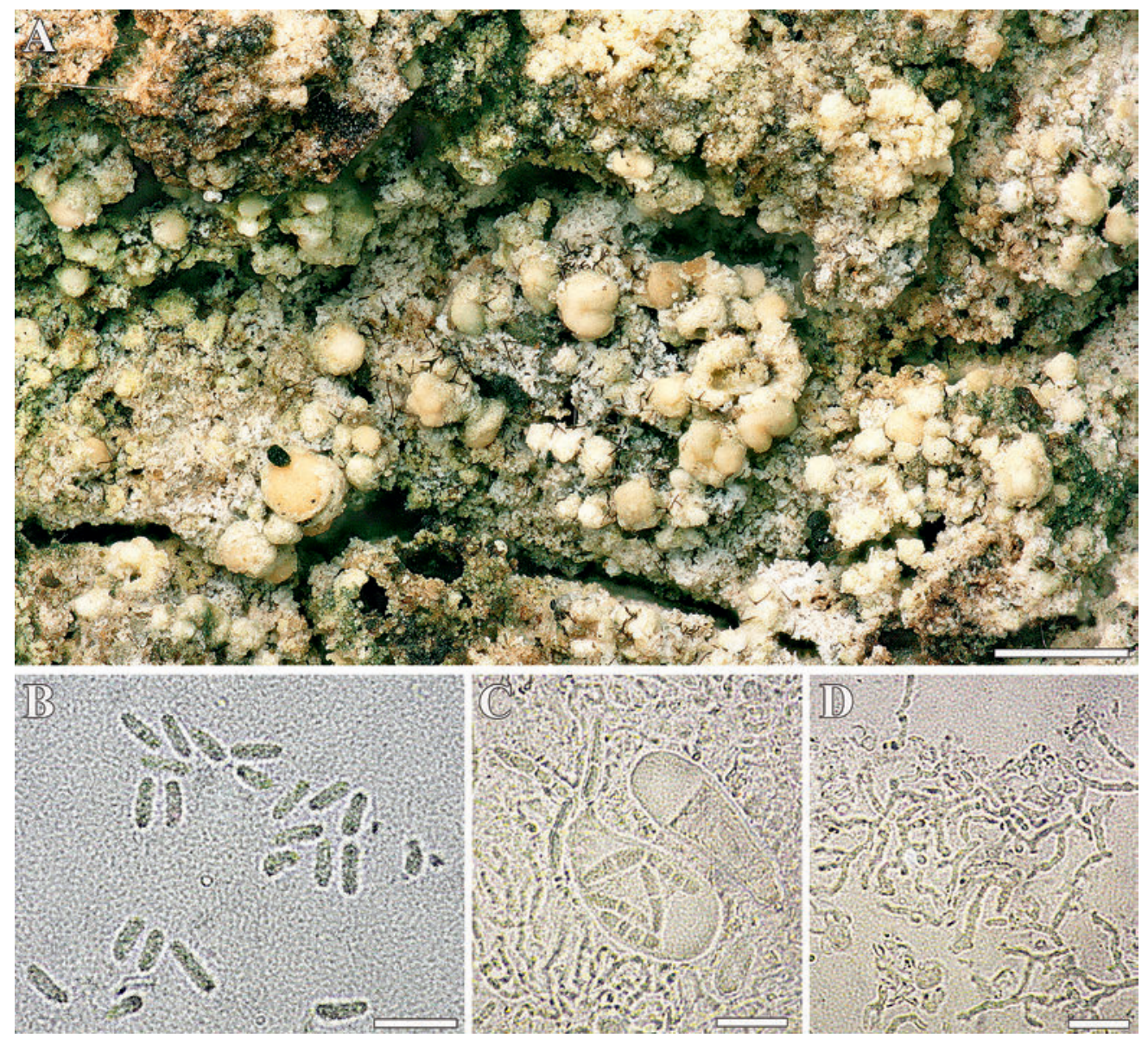

Figure 1: Micarea sambuci (holotype). - A) Habitus. - B) Mesoconidia. - C) Ascus with ascospores. - D) Paraphyses. Scales: $\mathrm{A}=0.2 \mathrm{~mm} ; \mathrm{B}=5 \mu \mathrm{m} ; \mathrm{C}, \mathrm{D}=10 \mu \mathrm{m}$. 
Table 1: Main differences between Micarea sambuci and Micarea nitschkeana.

\begin{tabular}{|l|l|l|}
\hline & M. nitschkeana & M. sambuci \\
\hline apothecia disc & $\begin{array}{l}(0.2-) 0.25-0.4 \mathrm{~mm} \\
\text { dark grey, dark brown to blackish }\end{array}$ & $\begin{array}{l}0.15-0.25 \mathrm{~mm} \\
\text { whitish, pale grey to medium brown }\end{array}$ \\
\hline apothecia margin & indistinct when young & persistent \\
\hline epihymenium & with loose paraphyses & with dense interwoven paraphyses \\
\hline paraphyses & never sinuous & sinuous near top \\
\hline mesoconidia & - & $100 \%$ \\
\hline macroconidia & c. $77 \%$ & - \\
\hline microconidia & c. $37 \%$ & - \\
\hline ecology & acidic bark & acidificated (dead) bark \\
\hline
\end{tabular}

\section{Acknowledgement}

We wish to thank Pawel CZARNOTA for his data about conidia of Micarea nitschkeana in Poland.

\section{References}

BLWG 2018: Micarea. - In: Verspreidingsatlas korstmossen. 10 Januari 2018. URL: http://www.verspreidingsatlas. $\mathrm{nl} / 4660$.

Brand A.M., van DEN Boom P.P.G. \& Sérusiaux E. 2014: Unveiling a surprising diversity in the lichen genus Micarea (Pilocarpaceae) in Réunion (Mascarenes archipelago, Indian Ocean). - The Lichenologist 46: 413-439.

Czarnota P. 2007: The lichen genus Micarea (Lecanorales, Ascomycota) in Poland. - Polish Botanical Studies 23. W. Szafer Institute of Botany, Polish Academy of Sciences (Kraków). 199 pp.

CoppIns B.J. 1983: A taxonomic study of the lichen genus Micarea in Europe. - Bulletin of the British Museum (Natural History), Botany Series 11: 17-214.

Orange A., James P.W. \& White F.J. 2010: Microchemical Methods for the Identification of Lichens (2 ${ }^{\text {nd }}$ edition). British Lichen Society (London).

Manuscript accepted: 08 March 2018

Communicated by: Toby Spribille

\section{Addresses of the authors}

Pieter P.G. van den BOOM, Arafura 16, NL-5691 JA Son, The Netherlands. E-mail: pvdboom@kpnmail.nl

A. Maarten BRAND, Klipperwerf 5, NL-2317 DX Leiden, The Netherlands. E-mail: a.maartenbrand@gmail.com

Brian COPPINS, Royal Botanic Garden Edinburgh, 20A Inverleith Row, Edinburgh, EH3 5LR, UK. - E-mail: lichensel@btinternet.com

Emmanuël SÉRUSIAUX, Evolution and Conservation Biology Unit, University of Liège, Sart Tilman B22, Quartier Vallée 1, Chemin de la vallée 4, B-4000 Liège, Belgium. E-mail: E.Serusiaux@ulg.ac.be 